\title{
IMPACT OF CEDZYNA RESERVOIR ON SELECTED PHYSICOCHEMICAL PARAMETERS OF RIVER WATER QUALITY (SWIETOKRZYSKIE MOUNTAINS, POLAND)
}

\author{
WPLYW ZBIORNIKA CEDZYNA NA WYBRANE PARAMETRY \\ FIZYKOCHEMICZNE JAKOŚCI WODY (GÓRY ŚWIĘTOKRZYSKIE, POLSKA)
}

\begin{abstract}
The monitoring of selected physicochemical parameters and chemical composition of water was conducted in 2017-2018 in the Lubrzanka river and the Cedzyna reservoir (Swietokrzyskie Mountains, Poland). The results indicate that the impact of reservoir on the quality of river water depends on natural characteristics of the catchment as well as on the present anthropogenic pressure. Retention of water in the reservoir caused seasonally diversified changes in analysed parameters, including an increase in water temperature, retention of major ions, nutrients and trace elements. Further research is needed to assess the risk of contamination of lower course of the river with metals deposited in reservoir's bottom sediments.
\end{abstract}

Keywords: water chemistry, trace elements, nitrate, environmental monitoring

\section{Introduction}

Dam reservoirs affect river ecosystems altering habitats, reducing natural flow variability, changing sediment load, severing upstream-downstream linkages, impairing dispersal of living organisms and changing water temperature and chemical composition $[1,2]$. The impact on particular physicochemical parameters of water depends on the geology and land use in catchment areas, as well as on the construction of the reservoir [3-5]. Having relatively large watersheds compared to natural lakes, dam reservoirs are affected by inputs of nutrients and sediments $[6,7]$. Reservoirs in river catchments which are under strong anthropopressure are vulnerable to inflow of pollutants and disturbance of self-cleaning processes, therefore the outflowing water can contaminate river below the dam. In the conditions of low human pressure reservoirs have a positive influence on water quality, due to retention of pollutants [8,9]. Biogeochemical processes in aquatic ecosystems, which affect water quality, are determined by transport and mixing of water masses, therefore another factor crucial for the dams' impact on rivers is the residence time of water in reservoirs [10, 11]. Apart from reservoir capacity, main functions and

\footnotetext{
${ }^{1}$ Institute of Geography and Environmental Sciences, Jan Kochanowski University in Kielce, ul. Uniwersytecka 7, 25-406 Kielce, Poland, phone +48 4134963 72, email: rafal.kozlowski@ujk.edu.pl

* Corresponding author: joanna.przybylska@tbop.org.pl
} 
management patterns, residence time depends on local climatic conditions, regulating magnitude and timing of river flows $[12,13]$. In consequence, reservoir's impact upon river ecosystem is determined by numerous factors and in each case it should be evaluated separately [14]. The aim of the research was to assess the influence of Cedzyna reservoir on the quality of water in the Lubrzanka river. A year of monitoring of selected physicochemical parameters resulted in characterising seasonal changes in the reservoir's impact.

\section{Research area and methods}

Artificial reservoir Cedzyna, built in the 1970s, impounds water from the Lubrzanka river and its two small tributaries with a surface-release dam. The catchment of this upland stream, flowing into the Nida river (Vistula drainage area) is located in the Swietokrzyskie Mountains [15]. Catchment area of the Lubrzanka river above the reservoir amounts to $114.4 \mathrm{~km}^{2}$ and the river's length from springs to reservoir's backwater is $17.8 \mathrm{~km}$. Geology of the area is complex and the main types present in the catchment are Cambrian and Devonian sandstones, as well as Pleistocene deposits, including loess covers [16]. Lubrzanka is a river of nivo-pluvial regime, with dominance of surface alimentation (over $65 \%$ ). Diversified relief with steep slopes (up to $20^{\circ}$ ), as well as poorly permeable bed of drainage area, generate overland and subsurface flow, therefore the fluctuations in discharge throughout the season are significant [17]. At the standard water lifting the volume of Cedzyna reservoir is 1.5 million $\mathrm{m}^{3}$, surface area - 64 ha and the mean depth $2.5 \mathrm{~m}$. Water residence time of about one month classifies the reservoir as intermediate - in the part near the inflow similar in terms of biogeochemical processes to a slow-flowing river, while in the part adjacent to the dam - similar to a lake [18]. The siltation of the reservoir is not significant and its predicted life span is calculated at ca. 300-700 years [19]. The reservoir was constructed mainly for recreation; it is also used for storing water for agricultural purposes. It was not designed for flood control and can not be modified for this purpose [19].

The monitoring of selected water quality indicators was conducted once a month from May 2017 to April 2018. Two sampling points were located in the river's course $-150 \mathrm{~m}$ above the reservoir's backwater and $70 \mathrm{~m}$ below the dam, and three points were located in the reservoir's littoral zone (Fig. 1). Water temperature $(T), \mathrm{pH}$, specific electrical conductivity $(S E C)$ and concentration of dissolved oxygen $(D O)$ were measured with the use of EUTECH PCD650 meter. Water samples were collected for further analyses in the Laboratory of Environmental Research in the Department of Environmental Protection and Modelling of the Jan Kochanowski University in Kielce.

Concentration of major ions $\left(\mathrm{Ca}^{2+}, \mathrm{Na}^{+}, \mathrm{Mg}^{2+}, \mathrm{K}^{+}, \mathrm{SO}_{4}{ }^{2-}, \mathrm{Cl}^{-}, \mathrm{NO}_{3}{ }^{-}\right)$was determined with the use of ion chromatograph DIONEX ICS-3000 with the following analytical columns: IonPac CS16 3x250 mm (cation) and IonPac AS18 2x250 mm (anion). The content of hydrogencarbonate was analysed by titration with $0.1 \mathrm{M} \mathrm{HCl}$ with methyl orange as indicator. Concentrations of dissolved metals ( $\mathrm{Sr}, \mathrm{Zn}, \mathrm{Ni}, \mathrm{Cr}, \mathrm{Cu}, \mathrm{Co}$ ) were measured with the use of time of flight mass spectrometer ICP/MS-TOF Optimass from GBC Scientific Equipment.

Statistical analyses included the Shapiro-Wilk test of normality, and if the data tested were not normally distributed - nonparametric Mann-Whitney $U$ test for two independent samples at the significance level of $\alpha=0.05$, as well as the Pearson correlation coefficient 
and principal component analysis (PCA). The analyses were conducted in Statistica 13 programme.

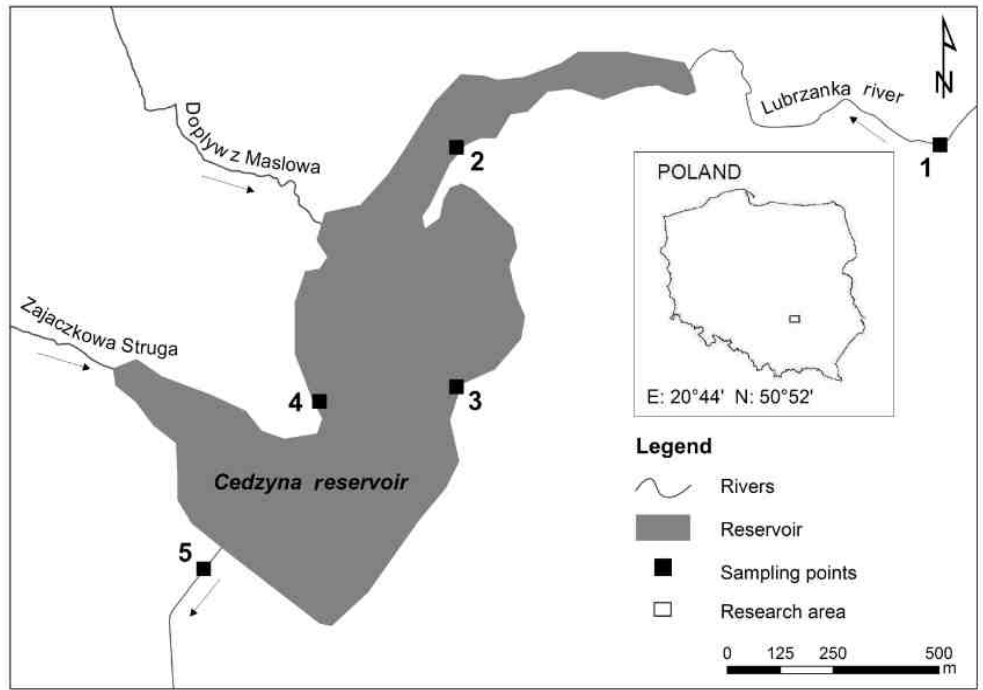

Fig. 1. Location of water sampling points in the Lubrzanka river and the Cedzyna reservoir

\section{Results and discussion}

\section{Physicochemical parameters}

The analysis of physicochemical parameters indicates that the retention of water in the Cedzyna reservoir causes changes in the quality of river water. The values of temperature, $\mathrm{pH}$ and concentration of dissolved oxygen were on average higher in the river's outflow from the reservoir than above its backwater, while specific electrical conductivity was reduced below the dam (Table 1).

Water temperature in the reservoir and the Lubrzanka river was changing throughout the year along with the changes in air temperature. The highest values were noted in spring and summer with the maximum of $22.6{ }^{\circ} \mathrm{C}$ in the reservoir's littoral zone in June. The difference between water temperature at the river inflow and outflow from the basin was the highest in August $\left(4.3^{\circ} \mathrm{C}\right)$. During summer the average increase in water temperature amounted to $3.2{ }^{\circ} \mathrm{C}$, mainly due to a relatively low mean depth of the reservoir and the construction of the dam, releasing heated water from the surface layers to the river below. Such effect is characteristic of small reservoirs [20, 21], while larger ones with bottom release dams decrease water temperature in lower course of rivers [22]. Concentration of dissolved oxygen was significantly negatively correlated with water temperature. Higher oxygen content in the river below the reservoir is connected with its turbulent flow from the dam and an adjacent artificial riffle. The differences in concentration of oxygen between the river inflow and outflow were greater during the growing season, which may result from the process of photosynthesis, particularly intense in surface layers of water [23, 24]. From January to April the values were similar and 
slightly lower at the river outflow than the inflow. During most of the year water in the Lubrzanka river above the reservoir had higher electrical conductivity than below the dam; however, in the autumn (September-December) concentration of major ions was generally higher at the outflow. Seasonal dynamics of conductivity in the released water was lower than that of the water flowing into the reservoir, which indicates that dissolved ions were cumulated in the reservoir. In the periods of low flow, river water of higher mineralisation mixes with diluted water masses, stored in the reservoir since high flow events [25].

Table 1

Values of selected physicochemical parameters of water from the Lubrzanka river and Cedzyna reservoir in 2017-2018

\begin{tabular}{|c|c|c|c|c|c|c|c|c|c|c|}
\hline \multirow[b]{2}{*}{ : } & \multicolumn{2}{|c|}{$\begin{array}{c}\text { Lubrzanka river - } \\
\text { inflow }\end{array}$} & \multicolumn{2}{|c|}{$\begin{array}{c}\text { Cedzyna reservoir } \\
\text { point } 2\end{array}$} & \multicolumn{2}{|c|}{$\begin{array}{c}\text { Cedzyna reservoi } \\
\text { point } 3\end{array}$} & \multicolumn{2}{|c|}{$\begin{array}{c}\text { Cedzyna reservoir } \\
\text { point } 4\end{array}$} & \multicolumn{2}{|c|}{$\begin{array}{c}\text { Lubrzanka river } \\
\text { outflow }\end{array}$} \\
\hline & \begin{tabular}{|c|}
$\begin{array}{c}\text { Mean } \\
\text { annual } \\
\text { (min.- } \\
\text { max.) }\end{array}$ \\
\end{tabular} & $S D$ & \begin{tabular}{|c|} 
Mean \\
annual \\
(min.- \\
max.)
\end{tabular} & $S D$ & \begin{tabular}{|c|} 
Mean \\
annual \\
(min.- \\
max.)
\end{tabular} & $S D$ & $\begin{array}{l}\text { Mean } \\
\text { annual } \\
\text { (min.- } \\
\text { max.) }\end{array}$ & $S D$ & $\begin{array}{c}\text { Mean } \\
\text { annual } \\
\text { (min.- } \\
\text { max.) }\end{array}$ & $S D$ \\
\hline$T\left[{ }^{\circ} \mathrm{C}\right]$ & $\begin{array}{c}\mathbf{9 . 1} \\
(0.0-19.6)\end{array}$ & 7.4 & $\begin{array}{c}\mathbf{1 0 . 6} \\
(0.0-23.1)\end{array}$ & 9.2 & $\begin{array}{c}\mathbf{1 1 . 4} \\
(0.0-24.0)\end{array}$ & 9.7 & $\begin{array}{c}11.9 \\
(0.6-24.6)\end{array}$ & 9.4 & $\begin{array}{c}11.1 \\
(0.5-21.9)\end{array}$ & 8.5 \\
\hline $\mathrm{pH}[-]$ & \begin{tabular}{|c|}
$\mathbf{7 . 0 4}$ \\
$(6.47-$ \\
$8.24)$ \\
\end{tabular} & 0.5 & \begin{tabular}{|c|}
$\mathbf{7 . 3 3}$ \\
$(6.49-$ \\
$8.40)$ \\
\end{tabular} & 0.7 & \begin{tabular}{|c|}
$\mathbf{7 . 5 2}$ \\
$(6.50-$ \\
$8.39)$ \\
\end{tabular} & 0.7 & \begin{tabular}{|c|}
$\mathbf{7 . 0 1}$ \\
$(6.47-$ \\
$7.75)$ \\
\end{tabular} & 0.4 & $\begin{array}{c}\mathbf{7 . 3 1} \\
(6.50- \\
8.36) \\
\end{array}$ & 0.5 \\
\hline $\begin{array}{c}S E C \\
{\left[\mu \mathrm{S} \cdot \mathrm{cm}^{-1}\right]}\end{array}$ & $\begin{array}{c}\mathbf{2 4 0 . 3} \\
(164.8- \\
313.5)\end{array}$ & 39.3 & $\begin{array}{r}212.1 \\
(164.2- \\
248.9)\end{array}$ & 25.6 & $\begin{array}{c}\mathbf{1 9 4 . 5} \\
(103.4- \\
235.8)\end{array}$ & 41.0 & $\begin{array}{c}213.7 \\
(181.6- \\
257.0)\end{array}$ & 25.1 & $\begin{array}{c}\mathbf{2 1 8 . 8} \\
(188.4- \\
242.4)\end{array}$ & 15.4 \\
\hline$D O\left[\mathrm{mg} \cdot \mathrm{dm}^{-3}\right]$ & $\begin{array}{c}\mathbf{9 . 3} \\
(5.3-12.4)\end{array}$ & 2.4 & $\begin{array}{c}\mathbf{1 0 . 0} \\
(6.7-14.0)\end{array}$ & 2.3 & $\begin{array}{c}\mathbf{1 0 . 2} \\
(7.8-12.2)\end{array}$ & 1.5 & $\begin{array}{c}\mathbf{9 . 1} \\
(7.0-12.3)\end{array}$ & 1.5 & $\begin{array}{c}\mathbf{9 . 8} \\
(6.8-12.1)\end{array}$ & 2.1 \\
\hline
\end{tabular}

$S D$ - standard deviation, $T$ - temperature, $S E C$ - specific electrical conductivity, $D O$ - dissolved oxygen

The average value of $\mathrm{pH}$ in the Lubrzanka river outflow was higher than above the reservoir and the differences were more distinct during growing season. Such impact is characteristic of small and medium, shallow reservoirs and, as in the case of changes in the concentration of dissolved oxygen, can be connected with the process of photosynthesis $[26,27]$. The results of Mann-Withney tests indicate that the differences in the values of discussed parameters between the river inflow and outflow are statistically insignificant.

\section{Major ions}

The concentrations of major ions in the Lubrzanka river were lower below the dam than above the reservoir in warm half-year (April-September), while in cold period (October-March) the values differed and were generally higher in the river outflow than in the inflow (Fig. 2). The analysis of average annual concentration values shows the reservoir's capacity to retain major ions and nitrates (Table 2).

In natural conditions, undisturbed by human pressure, concentration of major ions in river water increases with the growth of catchment area [1]. In the present research the majority of analysed ions had slightly lower average concentrations at the river outflow from the reservoir than above the reservoir. In the case of $\mathrm{NO}_{3}{ }^{-}$and $\mathrm{Na}^{+}$the differences between the values noted in river water above and below the reservoir were statistically significant (Mann-Whitney $U$ test, $p$-value $=0.04$ ). The highest reduction in the river outflow, amounting to $40 \%$, was noted for nitrate, particularly effectively retained in the 
reservoir during growing season. Similar values and seasonal dynamics of nitrate retention were found in the study of dam reservoir on the Por river [27].

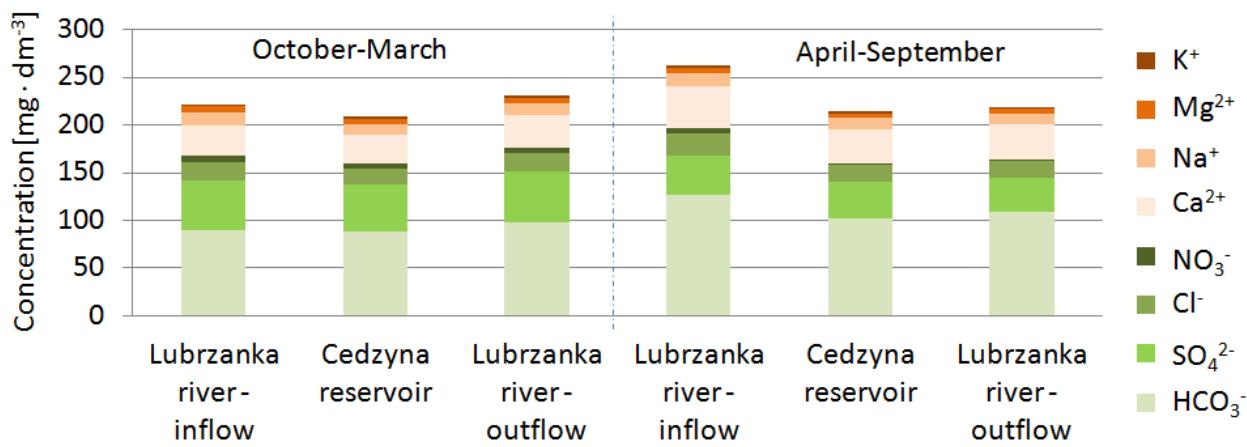

Fig. 2. Average concentrations of major ions in the Lubrzanka river and Cedzyna reservoir (average from 3 sampling points) in cold (left) and warm (right) half-year

Table 2

Concentrations of major ions and nitrate in water in the Lubrzanka river and Cedzyna reservoir in 2017-2018

\begin{tabular}{|c|c|c|c|c|c|c|c|c|c|c|}
\hline \multirow{2}{*}{ 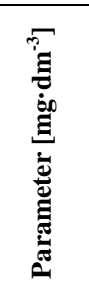 } & \multicolumn{2}{|c|}{$\begin{array}{l}\text { Lubrzanka } \\
\text { river - inflow }\end{array}$} & \multicolumn{2}{|c|}{$\begin{array}{c}\text { Cedzyna } \\
\text { reservoir } \\
\text { point } 2 \\
\end{array}$} & \multicolumn{2}{|c|}{$\begin{array}{c}\text { Cedzyna } \\
\text { reservoir } \\
\text { point } 3 \\
\end{array}$} & \multicolumn{2}{|c|}{$\begin{array}{c}\text { Cedzyna } \\
\text { reservoir } \\
\text { point } 4\end{array}$} & \multicolumn{2}{|c|}{$\begin{array}{l}\text { Lubrzanka } \\
\text { river - outflow }\end{array}$} \\
\hline & 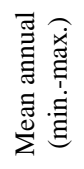 & $\ddot{\omega}$ & 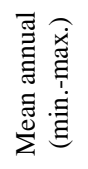 & ڤิ & 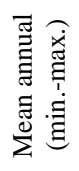 & $\stackrel{\leftrightarrow}{\varsigma}$ & 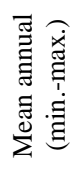 & ఉి & 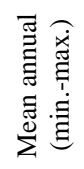 & $\ddot{\sim}$ \\
\hline $\mathrm{HCO}_{3}^{-}$ & $\begin{array}{l}\mathbf{1 0 8 . 5} \\
(61.0- \\
185.4) \\
\end{array}$ & 42.7 & $\begin{array}{c}\mathbf{9 5 . 1} \\
(39.0- \\
146.4) \\
\end{array}$ & 32.8 & $\begin{array}{c}\mathbf{9 1 . 6} \\
(48.8- \\
141.5) \\
\end{array}$ & 26.4 & $\begin{array}{r}\mathbf{9 7 . 5} \\
(57.3- \\
140.3) \\
\end{array}$ & 23.7 & $\begin{array}{l}\mathbf{1 0 3 . 6} \\
(48.8- \\
150.1)\end{array}$ & 26.7 \\
\hline $\mathrm{SO}_{4}{ }^{2-}$ & $\begin{array}{c}\mathbf{4 6 . 2} \\
(27.4- \\
75.6)\end{array}$ & 13.7 & $\begin{array}{c}\mathbf{4 6 . 5} \\
(28.3- \\
79.2)\end{array}$ & 14.4 & $\begin{array}{c}41.3 \\
(18.5- \\
64.6)\end{array}$ & 13.3 & $\begin{array}{r}\mathbf{4 5 . 7} \\
(28.5- \\
66.2)\end{array}$ & 11.7 & $\begin{array}{c}\mathbf{4 4 . 6} \\
(26.9- \\
64.9)\end{array}$ & 12.0 \\
\hline $\mathrm{Cl}^{-}$ & $\begin{array}{c}\mathbf{2 1 . 9} \\
(13.4- \\
34.2) \\
\end{array}$ & 5.7 & $\begin{array}{c}\mathbf{1 7 . 6} \\
(11.8- \\
21.6) \\
\end{array}$ & 3.3 & $\begin{array}{l}\mathbf{1 6 . 5} \\
(9.5- \\
21.4) \\
\end{array}$ & 3.9 & $\begin{array}{r}\mathbf{1 7 . 9} \\
(11.7- \\
22.7)\end{array}$ & 3.2 & $\begin{array}{c}\mathbf{1 8 . 2} \\
(11.8- \\
21.6)\end{array}$ & 2.8 \\
\hline $\mathrm{NO}_{3}{ }^{-}$ & $\begin{array}{c}\mathbf{5 . 5} \\
(3.4- \\
8.6)\end{array}$ & 1.4 & $\begin{array}{c}\mathbf{3 . 4} \\
(0.1- \\
7.9)\end{array}$ & 2.5 & $\begin{array}{c}\mathbf{3 . 1} \\
(0.2- \\
6.5)\end{array}$ & 2.4 & $\begin{array}{c}\mathbf{3 . 0} \\
(0.1- \\
5.9)\end{array}$ & 2.2 & $\begin{array}{c}\mathbf{3 . 5} \\
(0.1- \\
6.3)\end{array}$ & 2.2 \\
\hline $\mathrm{Ca}^{2+}$ & $\begin{array}{c}37.8 \\
(22.3- \\
61.0)\end{array}$ & 11.3 & $\begin{array}{c}33.1 \\
(21.8- \\
46.1)\end{array}$ & 7.2 & $\begin{array}{r}31.2 \\
(16.2- \\
45.2)\end{array}$ & 8.4 & $\begin{array}{r}\mathbf{3 4 . 2} \\
(23.4- \\
46.7)\end{array}$ & 6.4 & $\begin{array}{c}35.2 \\
(22.6- \\
46.7)\end{array}$ & 6.0 \\
\hline $\mathrm{Na}^{+}$ & $\begin{array}{l}\mathbf{1 3 . 9} \\
(9.8- \\
19.2)\end{array}$ & 2.7 & $\begin{array}{l}\mathbf{1 1 . 6} \\
(8.6- \\
13.8)\end{array}$ & 1.7 & $\begin{array}{l}\mathbf{1 0 . 7} \\
(5.9- \\
13.3)\end{array}$ & 2.4 & $\begin{array}{l}\mathbf{1 1 . 8} \\
(8.5- \\
14.1)\end{array}$ & 1.6 & $\begin{array}{l}\mathbf{1 1 . 9} \\
(8.6- \\
13.5)\end{array}$ & 1.4 \\
\hline $\mathrm{Mg}^{2+}$ & $\begin{array}{c}\mathbf{5 . 7} \\
(3.3- \\
8.5)\end{array}$ & 1.7 & $\begin{array}{c}\mathbf{5 . 1} \\
(2.4- \\
8.1)\end{array}$ & 1.6 & $\begin{array}{c}\mathbf{4 . 5} \\
(2.5- \\
6.7)\end{array}$ & 1.2 & $\begin{array}{c}\mathbf{5 . 2} \\
(2.8- \\
8.4)\end{array}$ & 1.6 & $\begin{array}{c}\mathbf{5 . 4} \\
(2.5- \\
7.6)\end{array}$ & 1.5 \\
\hline $\mathrm{K}^{+}$ & $\begin{array}{c}2.5 \\
(1.2- \\
3.4)\end{array}$ & 0.6 & $\begin{array}{c}\mathbf{2 . 4} \\
(1.3- \\
3.3) \\
\end{array}$ & 0.6 & $\begin{array}{c}2.3 \\
(1.3- \\
3.5)\end{array}$ & 0.7 & $\begin{array}{c}\mathbf{2 . 5} \\
(1.5- \\
4.1)\end{array}$ & 0.8 & $\begin{array}{c}\mathbf{2 . 4} \\
(1.3- \\
3.8)\end{array}$ & 0.7 \\
\hline
\end{tabular}


The results from larger reservoirs on mountain rivers are not so explicit and indicate seasonal changes in reservoirs' capacity to retain nitrate [28]. Other ions for which the annual reduction amounted to 10-20\% were chlorine and sodium. Concentrations of $\mathrm{Cl}^{-}$ and $\mathrm{Na}^{+}$throughout the season were positively correlated. Maximum concentration values were generally lower at the river outflow, which may result from gradual release of diluted high flow waters [25] and mixing river water with that from reservoir's smaller tributaries and overland flow directly to the reservoir.

\section{Trace elements}

The content of trace elements was on average lower in the river outflow from the reservoir than in the inflow (Table 3). However, periodic increases of chromium, copper and zinc below reservoir were noted, which may indicate a release of metals from the reservoir's bottom sediments (Fig. 3).

Mean annual, minimum and maximum concentrations of selected trace elements in the Lubrzanka river and Cedzyna reservoir in 2017-2018

\begin{tabular}{|c|c|c|c|c|c|c|}
\hline $\begin{array}{c}\text { Parameter } \\
(\text { mean annual } \\
\text { min.- max) } \\
{\left[\mu \mathrm{g} \cdot \mathbf{d m}^{-3}\right]}\end{array}$ & $\mathbf{S r}$ & $\mathbf{Z n}$ & $\mathrm{Ni}$ & $\mathrm{Cr}$ & $\mathbf{C u}$ & Co \\
\hline $\begin{array}{c}\text { Lubrzanka river - } \\
\text { inflow }\end{array}$ & $\begin{array}{c}\mathbf{9 4 . 4} \\
61.7-153.9 \\
\end{array}$ & $\begin{array}{c}\mathbf{7 . 2} \\
0.0-38.0 \\
\end{array}$ & $\begin{array}{c}\mathbf{4 . 8} \\
1.4-16.0 \\
\end{array}$ & $\begin{array}{c}\mathbf{4 . 2} \\
0.3-10.2 \\
\end{array}$ & $\begin{array}{c}\mathbf{1 . 5} \\
0.0-6.7 \\
\end{array}$ & $\begin{array}{c}\mathbf{0 . 4} \\
0.0-3.1 \\
\end{array}$ \\
\hline $\begin{array}{c}\text { Cedzyna reservoir } \\
\text { (average, minimum } \\
\text { and maximum values } \\
\text { from points 2-4) }\end{array}$ & $\begin{array}{c}\mathbf{8 1 . 8} \\
38.0-143.7\end{array}$ & $\begin{array}{c}\mathbf{5 . 9} \\
0.0-24.5\end{array}$ & $\begin{array}{c}\mathbf{3 . 8} \\
0.9-13.8\end{array}$ & $\begin{array}{c}\mathbf{3 . 4} \\
0.0-16.2\end{array}$ & $\begin{array}{c}\mathbf{0 . 9} \\
0.0-4.6\end{array}$ & $\begin{array}{c}\mathbf{0 . 1} \\
0.0-0.9\end{array}$ \\
\hline $\begin{array}{c}\text { Lubrzanka river - } \\
\text { outflow }\end{array}$ & $\begin{array}{c}\mathbf{8 3 . 6} \\
51.6-127.7 \\
\end{array}$ & \begin{tabular}{|c|c|}
$\mathbf{4 . 0}$ \\
$0.0-9.3$ \\
\end{tabular} & $\begin{array}{c}\mathbf{3 . 0} \\
1.6-5.7 \\
\end{array}$ & $\begin{array}{c}\mathbf{3 . 2} \\
0.0-15.4 \\
\end{array}$ & $\begin{array}{c}\mathbf{0 . 6} \\
0.0-1.3 \\
\end{array}$ & $\begin{array}{c}\mathbf{0 . 1} \\
0.0-0.8 \\
\end{array}$ \\
\hline
\end{tabular}

a)

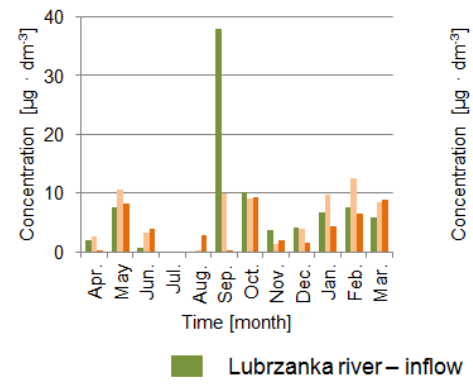

b)

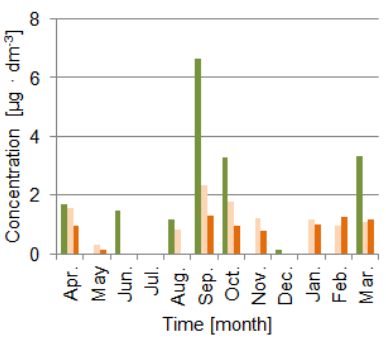

c)

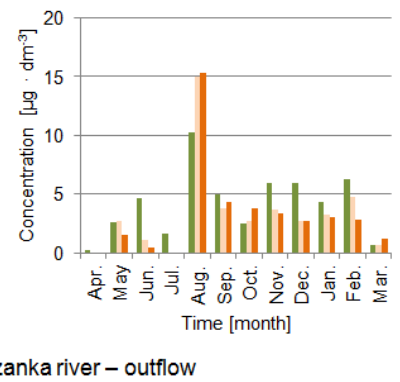

Fig. 3. Concentration of selected trace elements in the Lubrzanka river and the Cedzyna reservoir: a) zinc, b) copper and c) chromium

A significant anthropogenic source of trace elements in the water of Lubrzanka river is a periodic release of acid mine drainage waters from the "Wisniowka" quarry, located in the upper reaches of the river [29, 30]. It can explain the extreme values noted at the river inflow to the reservoir. Our results indicate the role of the reservoir in the self-cleaning 
processes. However, several trace elements were periodically noted in higher concentrations below the dam and it may be connected with the release from the sediments in the conditions of lower $\mathrm{pH}$, decomposition of organic matter or contamination from reservoir's small tributaries, with higher share of urbanised and agricultural areas in drainage basins [31-33].

\section{Statistical analyses}

Statistical analysis with the use of PCA identified four principal components PC1-PC4 (Table 4), which accounted for $81 \%$ of variability in the set of samples, regardless of the sampling point. For each component the eigenvalue was >1. PC1 represents natural conditions of the catchment area, while PC2-PC4 - anthropogenic impact.

The results of principal component analysis

\begin{tabular}{|c|c|c|c|c|}
\hline \multirow{2}{*}{ Variable } & \multicolumn{4}{|c|}{ Component } \\
\cline { 2 - 5 } & PC1 & PC2 & PC3 & PC4 \\
\hline $\mathrm{Cl}^{-}$ & $-0.83^{*}$ & -0.13 & -0.08 & -0.46 \\
\hline $\mathrm{SO}_{4}{ }^{2-}$ & -0.17 & 0.66 & 0.49 & 0.21 \\
\hline $\mathrm{NO}^{-}$ & -0.47 & 0.22 & 0.59 & 0.29 \\
\hline $\mathrm{Na}^{+}$ & $-0.83^{*}$ & -0.09 & -0.06 & -0.42 \\
\hline $\mathrm{Mg}^{2+}$ & $-0.80^{*}$ & -0.15 & 0.38 & 0.04 \\
\hline $\mathrm{Ca}^{2+}$ & $-0.87^{*}$ & -0.29 & -0.16 & 0.01 \\
\hline $\mathrm{K}^{+}$ & -0.72 & 0.05 & 0.50 & 0.13 \\
\hline $\mathrm{Zn}$ & 0.20 & $0.84^{*}$ & 0.10 & -0.13 \\
\hline $\mathrm{Ni}$ & -0.34 & 0.59 & $-0.64^{*}$ & -0.04 \\
\hline $\mathrm{Cr}$ & -0.35 & 0.07 & -0.59 & $0.62^{*}$ \\
\hline $\mathrm{Cu}$ & -0.14 & $0.81^{*}$ & -0.09 & -0.09 \\
\hline $\mathrm{Co}$ & -0.09 & $0.80^{*}$ & -0.08 & -0.19 \\
\hline $\mathrm{Sr}$ & $-0.85^{*}$ & 0.06 & -0.35 & 0.26 \\
\hline$\%$ of variance & 35 & 23 & 15 & 8 \\
\hline $\mathrm{Cumulative} \%$ & 35 & 58 & 73 & 81 \\
\hline
\end{tabular}

${ }^{*} \mathrm{PC} 1 \leq-0.8 ; \mathrm{PC} 2 \geq 0.8 ; \mathrm{PC} 3 \leq-0.6$ and $\mathrm{PC} 4 \geq 0.6$
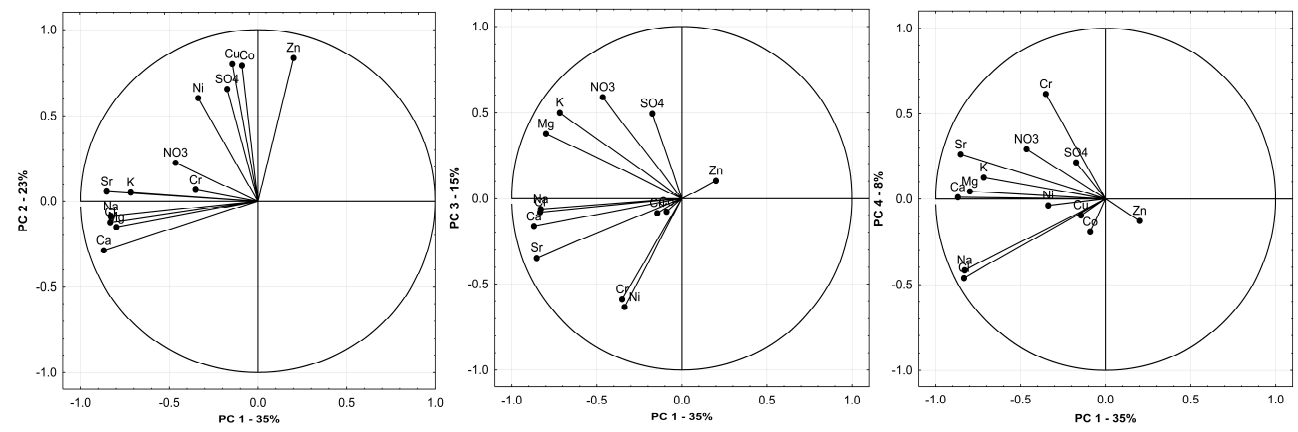

Fig. 4. PCA loading plots of selected physicochemical and chemical parameters of water in the Lubrzanka river

The first component (PC1), representing the influence of geology on the chemical composition of river water, generated as much as $35 \%$ of total variance and there were five 
variables with significant loadings $(\leq-0.8)$ on the component: $\mathrm{Cl}, \mathrm{Na}, \mathrm{Mg}, \mathrm{Ca}$ and $\mathrm{Sr}$ (Table 4). The second component ( $\mathrm{PC} 2 \geq 0.8$ ) stands for $23 \%$ of total variance and the highest loadings were those of $\mathrm{Zn}, \mathrm{Cu}$ and $\mathrm{Co}$ (Fig. 4), PC3 (15\% of variance) was connected with $\mathrm{Ni}(-0.64)$ and for PC4, which explained $8 \%$ of total variance, the significant loading (0.62) was noted for chromium (Fig. 4). The variables significant for PC2-PC4 were trace elements, which are found in higher concentrations in surface water contaminated with industrial and municipal waste discharges as well as overland flow from road network [34-36]. All the enumerated metals were detected in the upper course of the river in significantly higher concentrations than in other streams of the Swietokrzyskie Mountains [30].

\section{Summary and conclusion}

The analysis of selected physicochemical parameters and chemical composition of water in the Lubrzanka river and the Cedzyna reservoir revealed seasonally diversified changes in the analysed parameters caused by water retention in the reservoir. The most significant were: increase in water temperature, retention of major ions, nutrients and trace elements. Further research is needed to estimate the impact of overland flow to the basin and the inflow of water from two smaller reservoir's tributaries. Increasing acidification of water in the Lubrzanka upper course may pose a threat to self-cleaning processes in the reservoir, affecting release of metals deposited in bottom sediments. Therefore, the influence of the reservoir on water quality in the river should be monitored.

\section{References}

[1] Allan JD, Castillo MM. Stream Ecology. Structure and Functioning of Running Waters. Springer; 2007. Available from: https://chratye.cf/file-ready/stream-ecology-structure-and-function-of-running-waters-2ndedition.

[2] Dynesius M, Nilsson C. Science. 1994:266:753-62. DOI:10.1126/science.266.5186.753.

[3] Wiejaczka Ł, Prokop P, Kozłowski R, Sarkar S. Ecol Chem Eng S. 2018;25(1):73-88. DOI: 10.1515/eces-2018-0005.

[4] Wei GL, Yang ZF, Cui BS, Li B, Chen H, Bai JH, et al. Water Resour Manage. 2009:23:1763-80. DOI: 10.1007/s11269-008-9351-8.

[5] Ashby S, Kennedy R, Jabour W. Lake Reserv Manage. 1995:11(3):209-15. DOI: 10.1080/07438149509354201.

[6] Knoll L, Vanni M, Renwick W. Limnol Oceanogr. 2003:48(2):608-17. DOI: 10.4319/1o.2003.48.2.0608.

[7] Doubek J, Carey C. Inland Waters. 2017:7(2):171-80. DOI: 10.1080/20442041.2017.1293317.

[8] Wiatkowski M, Paul L. Surface water quality assessment in the Troja river catchment in the context of Włodzienin reservoir construction. Pol J Environ Stud. 2009:18(5):923-29. Available from: http://www.pjoes.com/Surface-Water-Quality-Assessment-in-the-Troja-r-nRiver-Catchment-in-the-Contextof, $88311,0,2 . \mathrm{html}$.

[9] Elias E, Dougherty M, Srivastava P, Laband D. Urban Ecosyst. 2013:16:79107. DOI: 10.1007/s11252-011-0198-Z.

[10] Rueda F, Moreno-Ostos E, Armengol J Ecol Modelling. 2006:191:260-74. DOI: 10.1016/j.ecolmodel.2005.04.030.

[11] Maneaux E, Probst J, Veyssy E, Etcheber H. Water Resour Res. 2001:37(3):801-11. DOI: 10.1029/2000WR900195.

[12] Winton RS, Calamita E, Wehrli B. Biogeosciences. 2019:16:1657-71. DOI: 10.5194/bg-16-1657-2019.

[13] Garg R, Rao R, Uchchariya D, Shula G, Saksena D. Afr J Environ Sci Technol. 2010:4(2):61-76. DOI: 10.5897/AJEST09.140.

[14] Friedl G, Wüest A. Aquat Sci. 2002:64:55-65. DOI: 1015-1621/02/010055-11.

[15] Solon J, Borzyszkowski J, Bidłasik M, Richling A, Bladora K, Balon J, et al. Geographia Polon. 2018:91(2):143-70. DOI: 10.7163/GPol.0115. 
[16] Filonowicz P. Detailed Geological Map of Poland 1:50000 Bodzentyn sheet. Warsaw: Wyd. Geologiczne; 1962. Available from: http://bazadata.pgi.gov.pl/data/smgp/arkusze_skany/smgp0816.jpg.

[17] Krupa J. Folia Quaternaria. 2013:81(1). DOI: 10.2478/folquart-2013-0001.

[18] Picińska-Fałtynowicz J, Błachuta J. Wytyczne metodyczne do przeprowadzenia monitoringu i oceny potencjału ekologicznego zbiorników zaporowych w Polsce. (Methodological guidance for conducting of monitoring and evaluation of ecological potential of reservoirs in Poland). Warszawa: IOŚ; 2012. Available from: http://www.gios.gov.pl/images/dokumenty/pms/monitoring_wod/Metodyki_biologiczne_zbiorniki_ zaporowe_wer_2010_2.pdf.

[19] Bodulski J, Górski J. J Water Land Dev. 2006:10(1):133-49. DOI: 10.2478/v10025-007-0011-9.

[20] Dripps W, Granger S. Environ Earth Sci. 2013:68:2399-407. DOI:10.1007/s12665-012-1924-4.

[21] Ignatius A, Rasmussen T. J Hydrol Reg Stud. 2016:8:145-61. DOI: 10.1016/j.ejrh.2016.08.005.

[22] Wiejaczka Ł, Kijowska-Strugała M, Pierwoła P, Nowak M. Geographia Polon. 2015:88(3):467-82. DOI: 10.7163/GPol.0029.

[23] Carr M, Sadeghian A, Lindenschmidt KE, Rinke K, Morales-Marin L. Environ Eng Sci. 2019:37(1):1-20. DOI: 10.1089/ees.2019.0146.

[24] Fairchild GW, Velinsky DJ. Lake Reserv. Manage. 2006:22(4):321-30. DOI: 10.1080/07438140609354366.

[25] Wiejaczka $Ł$. Wpływ zbiornika wodnego „Klimkówka” na abiotyczne elementy środowiska przyrodniczego w dolinie Ropy. (The influence of the Klimkówka water reservoir on the abiotic elements of the natural environment in the Ropa river valley). Prace Geograficzne IGiPZ PAN. 2011:229. Available from: https://rcin.org.pl/dlibra/publication/22183/edition/13280.

[26] Wang B, Liu CQ, Wang F, Liu XL, Wang ZL. Environ Earth Sci. 2015:73:5299-306. DOI: 10.1007/s12665-014-3779-3.

[27] Mazur A. Influence of the pre-dam reservoir on the quality of surface waters supplying reservoir „Nielisz”. Teka Kom Ochr. Kszt Środ Przyr OL PAN. 2010:7:243-50. Available from: https://www.semanticscholar.org/paper/Influence-of-the-pre-dam-reservoir-on-the-qualityMazur/d0f78ffb983e04fd5546a8889c7d1dc00fdbc257.

[28] Kijowska-Strugała M, Wiejaczka Ł, Kozłowski R. Ecol Chem Eng S. 2016:23(3):413-24. DOI: 10.1515/eces-2016-0029.

[29] Migaszewski Z. Gałuszka A, Dołęgowska S. Environ Sci Pollut Res. 2016:23:24943-59. DOI: 10.1007/s11356-016-7713-y.

[30] Przybylska J, Kozłowski R. Trace elements in water from selected rivers in the Świętokrzyskie Mountains. Monitoring Środowiska Przyrodniczego. 2018:20:61-9. Available from: https://www.researchgate.net/publication/338719889_TRACE_ELEMENTS_IN_WATER_FROM_SELEC TED_RIVERS_IN_THE_SWIETOKRZYSKIE_MOUNTAINS.

[31] Veselý J, Majer V. Water Air Soil Pollut. 1996:88:227-46. DOI: 10.1007/BF00294103.

[32] Kozłowski R, Przybylska J, Kaleta J. Monitoring Środowiska Przyrodniczego. 2017:19:81-9. Available from: https://www.monitoringsrodowiskaprzyrodniczego.pl/wplyw-zbiornika-zaporowego-cedzyna-nawybrane-parametry-jakosci-wody-rzeki-lubrzanki-w-okresie-letnim/

[33] Korfali SI, Davies BE. Environ Geochem Health. 2005:27:385-95. DOI: 10.1007/s10653-004-7096-8.

[34] Pekey H, Karakaş D, Bakog`lu M. Mar Pollut Bull. 2004:49:809-18. DOI: 10.1016/j.marpolbul.2004.06.029.

[35] Pratt C, Lottermoser B. Environ Geol. 2007:52:437-48. DOI: 10.1007/s00254-006-0471-2.

[36] Huser B, Kőhler S, Wilander A, Johansson K, Főlster J. Biogeosciences. 2001:8:1813-23. DOI: 10.5194/bg-8-1813-2011. 